\title{
Single and Multiple Viral Infections in Lower Respiratory Tract Infection
}

\author{
Mikael Gencay ${ }^{\mathrm{a}}$ Michael Roth ${ }^{\mathrm{a}}$ Mirjam Christ-Crain ${ }^{c}$ Beat Mueller \\ Michael Tamm ${ }^{\mathrm{a}}$ b Daiana Stol $z^{\mathrm{b}}$ \\ a Pulmonary Cell Research, b Pulmonary Medicine and ' Endocrinology, Department of Biomedicine, \\ University Hospital Basel and University of Basel, Basel, Switzerland
}

\section{For editorial comment see p. 443}

\section{Key Words}

Lower respiratory infections - Respiratory viruses •

Immunoglobulin $\mathrm{G} \cdot$ Immunoglobulin M

\begin{abstract}
Background: Lower respiratory tract infection (LRTI) often leads to hospitalization, and it was indicated that causative viral infections are underestimated. Objectives: It was our aim to compare the frequency of 8 relevant viruses in 109 hospitalized LRTI patients and 144 healthy controls. Methods: Virus infection was determined by seroconversion and ELISA for anti-virus antibodies in repeated serum samples. Bacterial infection was diagnosed in respiratory specimens, blood cultures and urine. Results: The LRTI patient cohort consisted of 49 patients with community-acquired pneumonia, 30 patients with acute bronchitis and 30 chronic obstructive pulmonary disease patients with acute exacerbation. Viral infection was detected in 89 (82\%) LRTI patients compared with 32 (22\%) in healthy controls (relative risk 3.42 , $95 \%$ confidence interval 2.48-4.72; $p<0.0001)$. The most frequent viral pathogens were: influenza B (23\%), adenovirus (16\%) and parainfluenza virus 3 (12\%). Importantly, infections with more than 1 virus were detected in $63 \%(n=57)$ of LRTI patients with viral infection, which represents $52 \%$ of all LRTI patients. No multiple virus infection was detected in the
\end{abstract}

healthy controls. Patients with community-acquired pneumonia were more often infected with adenovirus and respiratory syncytial virus as compared with the other LRTI patients ( $p=0.046$ and 0.0009 , respectively). Conclusions: There is a high incidence of single and multiple viral infections in LRTI patients requiring hospitalization. The data indicate the need for regular virus diagnosis and the development of point of care tools that enables a fast diagnosis of the most common viruses and bacteria. The data also imply the need to consider antiviral therapy in positive LRTI cases.

Copyright $\odot 2010$ S. Karger AG, Basel

\section{Introduction}

Lower respiratory tract infection (LRTI) is the most frequent cause of hospitalization worldwide [1-7]. Over the past decade, several studies aimed to define parameters that allow the distinction between bacterial and viral infections causing LRTI. The methods used included polymerase chain reaction (PCR), procalcitonin determination and other clinical information [8-15]. However, the information obtained by medical history, physical examination, routine laboratory parameters and chest radiography is not sufficient for a clear differential diagnosis of the cause of LRTI. Virus diagnosis is difficult as the

\section{KARGER}

Fax +4161306 1234 E-Mail karger@karger.ch www.karger.com

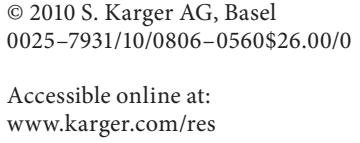

Pulmonary Cell Research, Department of Biomedicine

University Hospital Basel, Hebelstrasse 20

$\mathrm{CH}-4031$ Basel (Switzerland)

Tel. +41 61265 2337, Fax +4161265 2350,E-Mail rothmic@ uhbs.ch 
samples obtained may not be taken from an area in which the virus is present, and sampling with various methods was suggested by a recent study [16]. Rapid point of care diagnosis and differentiation of viral and bacterial infections in LRTI patients will improve patient management and help the decision to treat with antibiotics, or with new antiviral drugs, and in order to prevent the virus from spreading, such data might implement infection control.

Data of viral infection incidence in LRTI patients are scarce, and less than 70 publications addressed this issue during the past 5 years. All studies clearly indicated that viral infections in LRTI patients are underestimated even though it is the cause of more than $50 \%$ of hospitalizations. Unfortunately, most of these studies only investigated the presence of a single virus in a specific subset of LRTI patients. The fact that viral infections are difficult to treat should not lead to neglecting the diagnosis. Viral LRTI in early infancy was indicated to induce a predisposition to develop wheezing and asthma [17]. Viral infection is assumed to precede bacterial infections and may generate the environment for bacterial superinfections $[15,18,19]$. There is also evidence that viral infections make the lower respiratory tract more susceptible for fungal infections [20]. These findings indicate the need to develop new point of care tools for the diagnosis of viral infections and the differentiation from bacterial infections or the diagnosis of viral/bacterial coinfections. The argument that viral infections are difficult to treat still applies for most viruses; however, there are newly developed drugs, especially monoclonal antibodies that are virus specific and can be used to treat or even prevent viral infections $[21,22]$.

A further concern in LRTI patients is the occurrence of unwanted development of antibiotic-resistant bacteria strains. Bacterial infection is documented in approximately $25 \%$ of LRTI patients; however, the majority of LRTI patients are treated with antibiotics [5, 23, 24]. Despite therapy with antibiotics, the mortality and morbidity associated with LRTI is relevant and might be due to colonization with nonbacterial or antibiotic-resistant microorganisms $[2,6]$. LRTI caused by nonbacterial infection cannot be treated by antibiotic therapy, and for this condition, the use of antibiotics is known to lead to the occurrence of antibiotic resistance in clinically relevant bacteria [25].

The aim of this study was to determine the incidence of serological markers for the 8 most common community-acquired viral infections in a well-characterized LRTI population.

Multiviral Infection in LRTI

\section{Material and Methods}

\section{Setting and Study Population}

Data from a prospective monocentric trial including a total of 218 repeated serum samples obtained from 109 LRTI patients were analyzed. In brief, the main objective of the study was to evaluate procalcitonin-guided antibiotic de-escalation in LRTI as compared with usual care. The study took place at the emergency ward of the University Hospital Basel, Basel, Switzerland. The analysis of the incidence of virus infection by serology in the study population was a predefined secondary endpoint of the protocol. The study was approved by the institutional review board of Beider Basel. Written informed consent was obtained from all included patients or their legal representatives.

\section{Diagnostic Criteria}

The diagnosis of LRTI was established on the basis of clinical investigations, according to the following definitions: community-acquired pneumonia (CAP) was defined by a new infiltrate on chest X-ray together with cough, sputum production, dyspnea, fever $\left(>38.0^{\circ} \mathrm{C}\right)$, auscultatory abnormal breath sounds and rales. An additional criteria for LRTI was leukocytosis $\left(>10 \times 10^{9}\right.$ cells/l) or leukopenia $\left(<4 \times 10^{9}\right.$ cells/l) $[26,27]$. Acute bronchitis was defined by onset of cough 2-14 days (with or without sputum) prior to hospitalization in the absence of other lung disease or lung infiltrates (chest X-ray) according to a standard definition [28]. Acute exacerbation of chronic obstructive pulmonary disease (COPD) was defined as increased sputum, discolored sputum and/or dyspnea and a forced expiratory volume in $1 \mathrm{~s} /$ forced vital capacity ratio $<70 \%$ according to GOLD guidelines [29].

Baseline Assessment and Follow-Up

On admission, all patients were assessed according to a standardized protocol, including blood sampling for white blood counts, C-reactive protein, procalcitonin, blood cultures and a chest X-ray. The same blood samples were used for serological testing of antigens and/or antibodies for adenovirus, influenza $\mathrm{A}$ virus, influenza $B$ virus, parainfluenza virus type 1, parainfluenza virus type 2, parainfluenza virus type 3, respiratory syncytial virus (RSV), enterovirus (coxsackie B5 pool, echovirus), and for Mycoplasma pneumoniae, by an EIA screening kit (Anibiotech Orgenium Laboratories, Vantaa, Finland). Virus serology was considered positive if immunoglobulin (Ig)M was above established levels, and/or if seroconversion of IgG occurred comparing acute and convalescence serum samples, and/or in case very high levels of IgG were detected.

In patients presenting an infiltrate on chest X-ray, a search for Legionella pneumophilia antigen in urine was routinely performed. Sputum was collected cultures according to Murray's criteria for microbiological analysis. Bronchoalveolar lavage was performed and used for culture and/or PCR for L. pneumophilia, Chlamydia pneumoniae and M. pneumoniae. Control serum samples were collected from 144 healthy controls within the same period.

All tests were performed on admission and repeated at followup examinations after 2-3 weeks.

\section{Laboratory Parameters and Definitions}

White blood cell differentiation and counts were determined by flow cytometry according to standard procedures (MaxM; 
Table 1. Criteria and cutoff values for virus serology

\begin{tabular}{llll}
\hline & Type of antigens used in the EIA tests & IgG high positive & IgM positive \\
\hline Adenovirus & adenovirus type 6 & $\geq 130$ & $\geq 30$ \\
\hline Enterovirus & $\begin{array}{l}\text { B5 Faulkner strain and echovirus 9 } \\
\text { A/Beijing/262/95 (H1N1), Panama/2007/99 (H3N2) }\end{array}$ & $\geq 100$ & \\
\hline Influenza A virus & New Caledonia/20/99 IVR 116 (H1N1), Kiev/301/94 (H3N2) & $\geq 100$ & $\geq 30$ \\
\hline Influenza B virus & Hong Kong 5/72 & $\geq 100$ & $\geq 30$ \\
\hline Parainfluenza virus type 1 & Sendai C35 strain & $\geq 100$ & $\geq 30$ \\
\hline Parainfluenza virus type 2 & Greer strain & $\geq 100$ & $\geq 30$ \\
\hline Parainfluenza virus type 3 & C-243 strain & $\geq 100$ & $\geq 30$ \\
\hline RSV & Long strain & $\geq 100$ & $\geq 30$ \\
\hline M. pneumoniae & strain FH & $\geq 100$ & $\geq 35$ \\
\hline
\end{tabular}

The definition for 'positive' IgM and IgG levels was based on data obtained in serum samples of 30 healthy controls by the use of purified antigens in an EIA test system. Values are presented as enzyme immunoassay unit. Enterovirus data are based on a pool of antigens specific for coxsackievirus B5 Faulkner strain and echovirus 9 isolates. For influenza A, we detected an antigen pool specific for the following strains: A/Beijing/262/95 (H1N1), Panama/2007/99 (H3N2), New Caledonia/20/99 IVR 116 (H1N1), and Kiev/301/94 (H3N2).

Coulter Beckmann, Krefeld, Germany). C-reactive protein was determined by turbidimetric assay using polyclonal goat anti-human antibodies (Tina-Quant ${ }^{\circledR}$, Hitachi 717; Roche Diagnostics $\mathrm{GmbH}$, Mannheim, Germany). Procalcitonin levels were determined by immunoluminometric assay (Kryptor ${ }^{\circledR}$ PCT; Brahms Diagnostica, Berlin, Germany).

The cutoff values of IgM and IgG levels were determined for each viral antigen in serum samples of 30 healthy controls (data not shown). IgM-positive samples were retested after removal of IgG and rheumatoid factor by IgM sample preparation reagent (Anibiotech Orgenium Laboratories).

Seroconversion was defined as change from negative to positive IgG or IgM levels, or by a $>4$-fold increase in the respective Ig level comparing 2 serum samples of each patient. Seroconversion was determined by complement fixation test in samples of 10 patients for all above mentioned microorganisms according to the manufacturer's instructions (Virion, Rueschlikon, Switzerland). Samples for the complement fixation test were titrated from 1 to 64 values to the IgG EIA. An increase of $\geq 50 \%$ in IgG EIA test absorbance value or EIA was equal to a 4 -fold titer rise in the complement fixation test. The percentage of EIA units was calculated as: [(difference EIA unit 2nd sample - EIA unit 1st sample) $\times 100] /($ EIA unit 1 st sample).

The definition for 'positive' IgM and IgG levels was based on data obtained in serum samples of 30 healthy controls by the use of purified antigens in an EIA test system. Values are presented as enzyme immunoassay unit. Enterovirus data were based on a pool of antigens specific for coxsackievirus B5 Faulkner strain and echovirus 9 isolates. For influenza $A$, we detected an antigen pool specific for the following strains: A/Beijing/262/95 (H1N1), Panama/2007/99 (H3N2), New Caledonia/20/99 IVR 116 (H1N1), and Kiev/301/94 (H3N2) (table 1).

\section{Statistical Analysis}

Discrete variables are expressed as counts, and continuous variables as means \pm SD or median (interquartile range). The 4 -field $\chi^{2}$ test was used to analyze frequency distribution for each virus species between the patient groups. A p value $<0.05$ was defined as significant. Data were analyzed using Statistical Package for Social Sciences (SPSS Inc., Chicago, Ill., USA; version 15 for Windows) and Sigma Plot (version 10 for Windows). The authors held and analyzed all data.

\section{Results}

\section{Patient Characteristics}

The mean age of the 109 LRTI patients was 64.8 years (range 23-94) including 63 males and 46 females. Final diagnoses were: 49 patients with CAP, 30 COPD patients with acute exacerbations, and 30 patients with acute bronchitis. Cough was reported by all patients, 85 patients $(73 \%)$ produced sputum, 61 patients $(52 \%)$ had discolored sputum and 78 patients (67\%) suffered from dyspnea. The mean body temperature of all patients on admission was $37.7^{\circ} \mathrm{C}$ (table 2). Leukocyte counts in CAP $\left(10.2 \times 10^{9} / 1\right)$ and acute exacerbation of COPD $(11.2 \times$ $\left.10^{9} / 1\right)$ patients were significantly higher compared with LRTI patients with acute bronchitis $\left(8.7 \times 10^{9} / 1 ; \mathrm{p}<\right.$ 0.02). The average C-reactive protein level in CAP patients $(171 \mathrm{mg} / \mathrm{ml})$ was significantly higher compared with all other groups $(\mathrm{p}<0.05)$. Similarly, procalcitonin 
Table 2. Patient characteristics and clinical parameters

\begin{tabular}{|c|c|c|c|c|c|}
\hline & $\begin{array}{l}\text { CAP } \\
(\mathrm{n}=49)\end{array}$ & $\begin{array}{l}\text { Acute bronchitis } \\
(\mathrm{n}=30)\end{array}$ & $\begin{array}{l}\text { AECOPD } \\
(\mathrm{n}=30)\end{array}$ & $\begin{array}{l}\text { Total } \\
(\mathrm{n}=109)\end{array}$ & $\begin{array}{l}\text { Healthy controls } \\
(\mathrm{n}=144)\end{array}$ \\
\hline Median age, years & $64.3[25-91]$ & $59.3[23-94]$ & $70.5[50-85]$ & 68 & $49.6[19-68]$ \\
\hline Males/females & $30 / 19$ & $13 / 17$ & $20 / 10$ & $61 / 48$ & $64 / 30$ \\
\hline Fever & $33(67.3)$ & $9(30)$ & $8(26.6)$ & $50(46.3)$ & 0 \\
\hline Cough & $46(93.9)$ & $30(100)$ & $30(100)$ & $106(97.2)$ & 0 \\
\hline Dyspnea & $28(57.1)$ & $16(53.3)$ & $30(100)$ & $74(67.8)$ & 0 \\
\hline Sputum & $32(65.3)$ & $21(70)$ & $29(96.6)$ & $82(75.2)$ & 0 \\
\hline Discolored sputum & $22(44.9)$ & $11(36.7)$ & $21(70)$ & $54(49.5)$ & 0 \\
\hline Median body temperature, ${ }^{\circ} \mathrm{C}$ & $38.3[37.4-39.1]$ & $37.3[36.8-38.0]$ & $37.3[36.9-38.2]$ & $37.8[37.0-38.6]$ & - \\
\hline Median leukocyte counts, $\times 10^{9} / 1$ & $11[7.1-18.3]$ & $3[6-10.1]$ & $3[7.4-11.6]$ & $9.5[6.9-13.4]$ & - \\
\hline Median C-reactive protein, mg/l & $160.6[84.4-242.3]$ & 30.6 [13.3-69.9] & $32.9[9.1-60.0]$ & $65[21.2-132.4]$ & - \\
\hline Median procalcitonin, ng/ml & $0.728[0.137-4.141]$ & $0.08[0.053-0.142]$ & $0.091[0.069-0.142]$ & $0.130[0.070-0.686]$ & - \\
\hline Positive blood cultures & $9(18.4)$ & 0 & 0 & $9(8.3)$ & - \\
\hline Positive sputum bacteriology & $13(26.5)$ & $1(3.3)$ & $14(46.7)$ & $28(25.7)$ & - \\
\hline Infiltrate on chest $\mathrm{X}$-ray & $49(100)$ & 0 & 0 & $49(44.9)$ & - \\
\hline Neoplastic disease & $6(12.2)$ & $1(3.3)$ & $2(6.7)$ & $9(8.2)$ & \\
\hline Liver disease & $5(10.2)$ & 0 & $1(3.3)$ & $6(5.5)$ & \\
\hline Congestive heart failure & $2(4.1)$ & $3(10)$ & $2(6.7)$ & $7(6.4)$ & \\
\hline CVI & $3(6.1)$ & $1(3.3)$ & $1(3.3)$ & $5(4.6)$ & \\
\hline Renal disease & $10(20.4)$ & $3(10)$ & $3(10)$ & $16(14.7)$ & \\
\hline
\end{tabular}

Figures in parentheses are percentages; figures in brackets are interquartile ranges. $\mathrm{AECOPD}=$ Acute exacerbation of COPD; $\mathrm{CVI}=$ cerebrovascular insult.

levels in CAP patients $(4.5 \pm 1.5 \mathrm{ng} / \mathrm{ml})$ were significantly higher as compared with all other groups $(\mathrm{p}<0.01)$. All patient characteristics and clinical parameters are summarized in table 2 .

\section{Bacteriology and Laboratory Parameters}

Bacterial infections other than M. pneumoniae were identified in 15 (12.8\%) LRTI patients: Streptococcus pneumoniae $4.3 \%(\mathrm{n}=5)$, enterobacteria $3.4 \%(\mathrm{n}=4)$, Haemophilus influenza 2.6\% ( $\mathrm{n}=3)$, Pseudomonas $2.6 \%$ $(\mathrm{n}=3)$, Klebsiella $0.8 \%(\mathrm{n}=1)$, M. pneumoniae $0.8 \%(\mathrm{n}=$ 1), and Staphylococcus aureus $0.8 \%(\mathrm{n}=1)$. Eight CAP patients presented positive blood cultures. Positive bacterial culture in respiratory specimens was found in 12 COPD patients with exacerbation, in $11 \mathrm{CAP}$ patients and in 1 patient with acute bronchitis.

\section{Viral Serology}

Compared with the control group, serological analysis indicated a significantly higher incidence of viral infections among LRTI patients $-89(82 \%)$ as compared with $32(22 \%)$ in healthy controls $(\mathrm{p}<0.0001)$. These data indicate a relative risk of 3.73 (95\% confidence interval 2.48-4.72) for viral infection in LRTI patients. The most frequent viral pathogens were: influenza B (23\%), adenovirus (16\%) and parainfluenza virus $3(12 \%)$. In addition, adenovirus, influenza A and B, parainfluenza 3 and RSV were found with a significant higher incidence in LRTI patients than in healthy controls (fig. 1). There was no significant difference in the incidences of enterovirus infection, and $M$. pneumoniae infection was similar in LRTI patients and controls (fig. 1). A detailed analysis of the incidence of viruses in the 3 LRTI groups is provided in figure 1.

Patients with CAP were more often infected with adenovirus and RSV as compared with patients with acute bronchitis and acute exacerbations of COPD ( $p=0.046$ and 0.0009, respectively) (fig. 2).

Infections with a single virus were observed in 56 (51\%) LRTI patients as compared with 22 controls (15\%; $\mathrm{p}<0.01)$. Multiple viral infections were detected in 30\% $(\mathrm{n}=33)$ of the viral infection cases among LRTI patients and in none of the healthy controls. No sign of virus or M. pneumoniae infection was found in 28 LRTI patients and in the majority of healthy controls (fig. 3).

Seroconversion for IgG and IgM against any of the evaluated viruses was detected in 33 and 34 patients with LRTI, respectively. Positive IgM levels for infection with virus or M. pneumoniae was observed in 22 patients on the day of hospital admission. Interestingly, none of these patients tested positive for IgM 14 days later (fig. 3). 
Fig. 1. Percentage of viral infection incidences in the 3 subgroups of LRTI patients. The percentage of virus infection was calculated on the total number of patients in each subgroup. Statistics were calculated by the $\chi^{2}$ test. AECOPD $=$ Acute exacerbation of COPD.
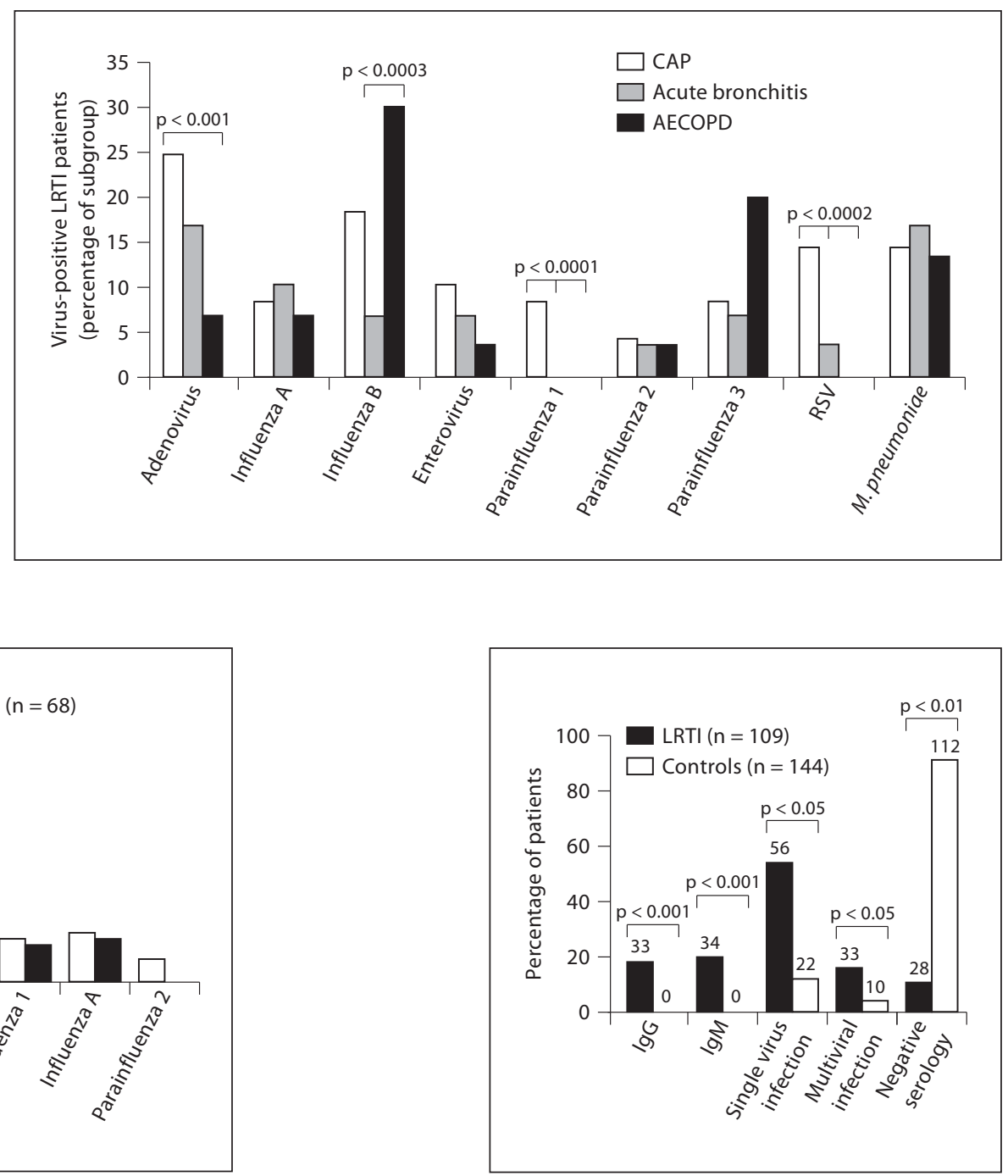

Fig. 3. The incidence of seroconversion and of single and multiple virus infection in 109 LRTI patients compared with healthy controls. Absolute numbers of affected probands are provided on top of each bar. Statistics were calculated by the $\chi^{2}$ test.

fections with more than 1 virus were observed in LRTI patients. And thirdly, CAP patients had the highest incidence of adenovirus and RSV infections.

New studies indicate that the prevalence of bacterial infection in LRTI has been overestimated earlier; on average, signs of bacterial infection can be documented in $25 \%$ of LRTI patients. In our cohort, the incidence of $13 \%$ is on the lower limit of the range $[5,23,24]$. We could not find any correlation between virus species and bacterial infections as has been suggested by other studies $[2,6,15,18,19]$. 
Increasing evidence suggests that virus infection in LRTI patients has been underestimated [3, 15, 30-35]. Our data are in agreement with previous studies which were based on virus isolation and culture from bronchoalveolar lavage samples, PCR results from throat swabs and/or serology [3, 36, 37]. Influenza B virus, adenovirus and parainfluenza virus 3 were the most common viruses in this LRTI patient cohort. The prevalence of influenza virus infection is not surprising as the European Influenza Surveillance Scheme reported a widespread medium level of influenza $(A+B)$ activity in Switzerland during the sampling period (www.eiss.org. EISS: Annual report: 2002-2003 influenza season. 2004). Compared with 5 recent studies, the cohort of this study had the largest incidence of infections with influenza $(A+B)$, parainfluenza 1-3 and RSV [16, 38-42]. This difference might be due to the sampling procedure and the fact that most other studies used PCR while we determined IgG and IgM levels in repeated serum samples.

Importantly, infection with more than 1 virus in a single patient was underestimated or ignored by earlier studies. In our cohort of LRTI patients, $30 \%$ showed serological evidence of multiviral infection. This is nearly double the frequency that was reported in other studies $[3,4,43$, 44]. The high rate of multiple viral infections could either be due to the virus species screened in this study, the patient-selection criteria, the sampling season, the geographic localization, or the age of the LRTI patients. To exclude the possibility that our data analysis for multiple viral infections was caused by cross-reactivity, we further analyzed the data for specific viral patterns. However, we observed only a random distribution of virus species in patients with multiple infections.

Interestingly, 2 very recent studies which included 550 and 219 patients, respectively, suggested that viral infections which are not characteristic for the respiratory tract were associated with LRTI; these included herpesviruses, cytomegalovirus and coronaviruses [42, 43].

Enterovirus infection in LRTI patients in this study was identified with a similar incidence reported in an Italian study [39], while it was significantly higher compared with the data reported in 2 other studies [38, 42]. This difference may be explained by the test systems or by the antigen. The enterovirus antigen used in this study was isolated from coxsackievirus B5 and echovirus 9 antigens that are known to cross-react with at least 10 different enterovirus-specific antibodies. Furthermore, a cross-reaction of this enterovirus antigen pool with rhinoviruses cannot be excluded. There are no data on coxsackievirus infection in adult LRTI patients, while cox- sackievirus was isolated from children with LRTI [43, 44].

In $28 \%$ of LRTI patients, we observed seroconversion of influenza viruses, parainfluenza, adenovirus and $M$. pneumoniae. Unfortunately, there is no comparable study to interpret this finding.

New studies provide evidence that there are options to treat viral infections in LRTI patients. Newly developed humanized monoclonal antivirus antibodies exist and have been used to successfully treat RSV [21, 22]. Similar drugs are in the stage of preclinical testing. One experimental in vitro study suggested that tiotropium bromide may also reduce RSV infection in epithelial cells [45]. Available antiviral drugs are: azithromycin for treatment of rhinovirus [46], chimeric antibodies specific for $\mathrm{H} 5 \mathrm{~N} 1$ [47], granzyme A for influenza A virus [48] and the combination of ribavirin with methylprednisolone for parainfluenza virus 3 [49]. These new and upcoming therapeutic options put more weight on the demand for point of care diagnostic tools in viral and bacterial infections in LRTI patients and further strengthen the argument to routinely screen viral infection in these patients.

In conclusion, our data show that infection with single and multiple virus species are found at high incidences in LRTI patients. Together with other studies, our data imply that the diagnosis of viruses in LRTI patients should be performed at the day of admission. This would help in patient management, treatment and prevention of virus spreading. We are aware that the available diagnostic tools for point of care diagnosis are not optimal and we are also aware that virus therapy has to be further improved. We hope that the findings of our study can alert clinicians regarding the risk of viral infection in LRTI patients and stimulate the development of diagnostic tools as well as therapeutic strategies.

\section{Acknowledgements}

This study was supported by the Clinic of Pneumology and Respiratory Cell Research of the University Hospital Basel, Basel, Switzerland. We thank Anibiotech Orgenium Laboratories, Vantaa, Finland, for providing the viral serological assays.

We would also like to thank Mr. C.T. S'ng for his help in preparing the manuscript. 


\section{References}

-1 Ahn KM, Chung SH, Chung EH, Koh YJ, Nam SY, Kim JH, Son JA, Park JY, Lee NY, Lee SI: Clinical characteristics of acute viral lower respiratory tract infections in hospitalized children in Seoul, 1996-1998. J Korean Med Sci 1999;14:405-411.

-2 Ellis SE, Coffey CS, Mitchel EF Jr, Dittus RS, Griffin MR: Influenza- and respiratory syncytial virus-associated morbidity and mortality in the nursing home population. J Am Geriatr Soc 2003;51:761-767.

3 Garbino J, Gerbase MW, Wunderli W, Kolarova L, Nicod LP, Rochat T, Kaiser L: Respiratory viruses and severe lower respiratory tract complications in hospitalized patients. Chest 2004;125:1033-1039.

-4 Lieberman D, Lieberman D, Ben-Yaakov M, Lazarovich Z, Ohana B, Friedman MG, Dvoskin B, Leinonen M, Boldur I: Infectious aetiologies in elderly patients hospitalised with non-pneumonic lower respiratory tract infection. Age Ageing 2003;32:95-101.

5 Macfarlane JT, Colville A, Guion A, Macfarlane RM, Rose DH: Prospective study of aetiology and outcome of adult lower-respiratory-tract infections in the community. Lancet 1993;341:511-514.

-6 Thompson WW, Shay DK, Weintraub E, Brammer L, Cox N, Anderson LJ, Fukuda K: Mortality associated with influenza and respiratory syncytial virus in the United States. JAMA 2003;289:179-186.

-7 Ekici M, Ekici A, Akin A, Altinkaya V, Bulcun E: Chronic airway diseases in adult life and childhood infections. Respiration 2008; 75:55-59.

8 Stolz D, Christ-Crain M, Morgenthaler NG, Leuppi J, Miedinger D, Bingisser R, Müller C, Struck J, Müller B, Tamm M: Copeptin, $\mathrm{C}$-reactive protein, and procalcitonin as prognostic biomarkers in acute exacerbation of COPD. Chest 2007;131:1058-1067.

\9 Kristoffersen KB, Søgaard OS, Wejse C, Black FT, Greve T, Tarp B, Storgaard M, Sodemann M: Antibiotic treatment interruption of suspected lower respiratory tract infections based on a single procalcitonin measurement at hospital admission - a randomized trial. Clin Microbiol Infect 2009;15: 481-487.

10 Moore M, Little P, Rumsby K, Kelly J, Watson L, Warner G, Fahey T, Williamson I: Effect of antibiotic prescribing strategies and an information leaflet on longer-term reconsultation for acute lower respiratory tract infection. Br J Gen Pract 2009;59:728-734.

-11 Bont J, Hak E, Hoes AW, Schipper M, Schellevis FG, Verheij TJ: A prediction rule for elderly primary-care patients with lower respiratory tract infections. Eur Respir J 2007;29: 969-975.
2 Stolz D, Christ-Crain M, Gencay MM, Bingisser R, Huber PR, Müller B, Tamm M: Diagnostic value of signs, symptoms and laboratory values in lower respiratory tract infection. Swiss Med Wkly 2006;136:434440.

13 Strälin K, Korsgaard J, Olcén P: Evaluation of a multiplex PCR for bacterial pathogens applied to bronchoalveolar lavage. Eur Respir J 2006;28:568-575.

14 Oosterheert JJ, van Loon AM, Schuurman R, Hoepelman AI, Hak E, Thijsen S, Nossent G, Schneider MM, Hustinx WM, Bonten MJ Impact of rapid detection of viral and atypical bacterial pathogens by real-time polymerase chain reaction for patients with lower respiratory tract infection. Clin Infect Dis 2005;41:1438-1444

15 Creer DD, Dilworth JP, Gillespie SH, Johnston AR, Johnston SL, Ling C, Patel S, Sanderson G, Wallace PG, McHugh TD: Aetiological role of viral and bacterial infections in acute adult lower respiratory tract infection (LRTI) in primary care. Thorax 2006;61: 75-79.

16 Lieberman D, Lieberman D, Shimoni A, Keren-Naus A, Steinberg R, Shemer-Avni Y: Identification of respiratory viruses in adults: nasopharyngeal versus oropharyngeal sampling. J Clin Microbiol 2009;47: 3439-3443.

17 Stein RT: Long-term airway morbidity following viral LRTI in early infancy: recurrent wheezing or asthma? Paediatr Respir Rev 2009;10(suppl 1):29-31.

18 Thorburn K, Harigopal S, Reddy V, Taylor N, van Saene HK: High incidence of pulmonary bacterial co-infection in children with severe respiratory syncytial virus (RSV) bronchiolitis. Thorax 2006;61:611-615.

19 Madhi SA, Ludewick H, Kuwanda L, Niekerk N, Cutland C, Little T, Klugman KP: Pneumococcal coinfection with human metapneumovirus. J Infect Dis 2006;193:12361243.

20 Martino R, Piñana JL, Parody R, Valcarcel D, Sureda A, Brunet S, Briones J, Delgado J, Sánchez F, Rabella N, Sierra J: Lower respiratory tract respiratory virus infections increase the risk of invasive aspergillosis after a reduced-intensity allogeneic hematopoietic SCT. Bone Marrow Transplant 2009;44: 749-756

21 Frogel MP, Stewart DL, Hoopes M, Fernandes AW, Mahadevia PJ: A systematic review of compliance with palivizumab administration for RSV immunoprophylaxis. J Manag Care Pharm 2010;16:46-58.

22 Simoes EA, Groothuis JR, Carbonell-Estrany X, Rieger $\mathrm{CH}$, Mitchell I, Fredrick LM, Kimpen JL, Palivizumab Long-Term Respiratory Outcomes Study Group: Palivizumab prophylaxis, respiratory syncytial virus, and subsequent recurrent wheezing. J Pediatr 2007;151:34-42, 42.e1.
23 Winchester CC, Macfarlane TV, Thomas M, Price D: Antibiotic prescribing and outcomes of lower respiratory tract infection in UK primary care. Chest 2009; 135:11631172 .

24 Jansen AG, Sanders EA, Schilder AG, Hoes AW, de Jong VF, Hak E: Primary care management of respiratory tract infections in Dutch preschool children. Scand J Prim Health Care 2006;24:231-236.

25 Christ-Crain M, Jaccard-Stolz D, Bingisser R, Gencay MM, Huber PR, Tamm M, Müller B: Effect of procalcitonin-guided treatment on antibiotic use and outcome in lower respiratory tract infections: cluster-randomised, single-blinded intervention trial. Lancet 2004;363:600-607.

26 Halm EA, Teirstein AS: Clinical practice. Management of community-acquired pneumonia. N Engl J Med 2002;347:2039-2045.

27 Nicolau D: Clinical and economic implications of antimicrobial resistance for the management of community-acquired respiratory tract infections. J Antimicrob Chemother 2002;50:61-70.

28 Niederman MS, Mandell LA, Anzueto A, Bass JB, Broughton WA, Campbell GD, Dean N, File T, Fine MJ, Gross PA, Martinez F, Marrie TJ, Plouffe JF, Ramirez J, Sarosi GA, Torres A, Wilson R, Yu VL, American Thoracic Society: Guidelines for the management of adults with community-acquired pneumonia. Diagnosis, assessment of severity, antimicrobial therapy, and prevention. Am J Respir Crit Care Med 2001;163:17301754.

29 Evans AT, Husain S, Durairaj L, Sadowski LS, Charles-Damte M, Wang Y: Azithromycin for acute bronchitis: a randomised, double-blind, controlled trial. Lancet 2002;359: 1648-1654.

-30 Anthonisen NR, Manfreda J, Warren CP, Hershfield ES, Harding GK, Nelson NA: Antibiotic therapy in exacerbations of chronic obstructive pulmonary disease. Ann Intern Med 1987;106:196-204.

- 31 National Asthma Education and Prevention Program: Expert panel report 3 (EPR-3): guidelines for the diagnosis and management of asthma. Summary report 2007. J Allergy Clin Immunol 2007;120:S94-S138.

- 32 Danés C, González-Martín J, Pumarola T, Rañó A, Benito N, Torres A, Moreno A, Rovira $\mathrm{M}$, Puig de la Bellacasa J: Pulmonary infiltrates in immunosuppressed patients: analysis of a diagnostic protocol. J Clin $\mathrm{Mi}$ crobiol 2002;40:2134-2140.

-33 Minosse C, Selleri M, Zaniratti MS, Cappiello G, Longo R, Schifano E, Spanò A, Petrosillo N, Lauria FN, Puro V, Capobianchi MR: Frequency of detection of respiratory viruses in the lower respiratory tract of hospitalized adults. J Clin Virol 2008;42: 215-220. 
-34 Garbino J, Gerbase MW, Wunderli W, Deffernez C, Thomas Y, Rochat T, Ninet B, Schrenzel J, Yerly S, Perrin L, Soccal PM, Nicod L, Kaiser L: Lower respiratory viral illnesses: improved diagnosis by molecular methods and clinical impact. Am J Respir Crit Care Med 2004;170:1197-1203.

-35 de Roux A, Marcos MA, Garcia E, Mensa J, Ewig S, Lode H, Torres A: Viral communityacquired pneumonia in nonimmunocompromised adults. Chest 2004;125:1343-1351.

-36 Johnstone J, Majumdar SR, Fox JD, Marrie TJ: Viral infection in adults hospitalized with community-acquired pneumonia: prevalence, pathogens, and presentation. Chest 2008;134:1141-1148.

>37 Garbino J, Soccal PM, Aubert JD, Rochat T, Meylan P, Thomas Y, Tapparel C, Bridevaux PO, Kaiser L: Respiratory viruses in bronchoalveolar lavage: a hospital-based cohort study in adults. Thorax 2009;64:399-404.

-38 Ren L, Gonzalez R, Wang Z, Xiang Z, Wang Y, Zhou H, Li J, Xiao Y, Yang Q, Zhang J, Chen L, Wang W, Li Y, Li T, Meng X, Zhang Y, Vernet G, Paranhos-Baccalà G, Chen J, Jin Q, Wang J: Prevalence of human respiratory viruses in adults with acute respiratory tract infections in Beijing, 2005-2007. Clin Microbiol Infect 2009;15:1146-1153.
39 Gambarino S, Mantovani S, Astegiano S, Libertucci D, Solidoro P, Baldi S, Cavallo R, Bergallo M, Costa C: Lower respiratory tract viral infections in hospitalized adult patients. Minerva Med 2009;100:349-356.

40 Blanquer J, Blanquer R, Borrás R, Nauffal D, Morales P, Menéndez R, Subías I, Herrero L, Redón J, Pascual J: Aetiology of community acquired pneumonia in Valencia, Spain: a multicentre prospective study. Thorax 1991; 46:508-511.

41 Lieberman D, Schlaeffer F, Boldur I, Lieberman D, Horowitz S, Friedman MG, Leiononen M, Horovitz O, Manor E, Porath A Multiple pathogens in adult patients admitted with community-acquired pneumonia: a one year prospective study of 346 consecutive patients. Thorax 1996;51:179-184.

42 Falsey AR, Treanor JJ, Betts RF, Walsh EE: Viral respiratory infections in the institutionalized elderly: clinical and epidemiologic findings. J Am Geriatr Soc 1992;40:115119.

43 Moore M, Kaplan MH, McPhee J, Bregman DJ, Klein SW: Epidemiologic, clinical, and laboratory features of Coxsackie B1-B5 infections in the United States, 1970-79. Public Health Rep 1984;99:515-522.

44 Mizuta K, Abiko C, Goto H, Murata T, Murayama S: Enterovirus isolation from children with acute respiratory infections and presumptive identification by a modified microplate method. Int J Infect Dis 2003; 7: 138-142.
45 Iesato K, Tatsumi K, Saito K, Ogasawara T, Sakao S, Tada Y, Kasahara Y, Kurosu K, Tanabe N, Takiguchi Y, Kuriyama T, Shirasawa $\mathrm{H}$ : Tiotropium bromide attenuates respiratory syncytial virus replication in epithelial cells. Respiration 2008;76:434-441.

46 Gielen V, Johnston SL, Edwards MR: Azithromycin induces anti-viral responses in bronchial epithelial cells. Eur Respir J 2010, Epub ahead of print.

-47 Prabakaran M, Prabhu N, He F, Hongliang Q, Ho HT, Qiang J, Meng T, Goutama M, Kwang J: Combination therapy using chimeric monoclonal antibodies protects mice from lethal $\mathrm{H} 5 \mathrm{~N} 1 \mathrm{infection}$ and prevents formation of escape mutants. PLoS One 2009; 4:e5672.

$\checkmark 48$ Moffat JM, Gebhardt T, Doherty PC, Turner SJ, Mintern JD: Granzyme A expression reveals distinct cytolytic CTL subsets following influenza A virus infection. Eur J Immunol 2009;39:1203-1210.

49 Shima T, Yoshimoto G, Nonami A, Yoshida $\mathrm{S}$, Kamezaki K, Iwasaki H, Takenaka K, Miyamoto T, Harada N, Teshima T, Akashi K, Nagafuji K: Successful treatment of parainfluenza virus 3 pneumonia with oral ribavirin and methylprednisolone in a bone marrow transplant recipient. Int J Hematol 2008; 88:336-340. 